ataxia and an abnormal EEG two weeks after a presumed meningoencephalitic illness with complete recovery over the ensuing three weeks. Hopkins and Michael $^{19}$ described a 36 year old male who developed rhythmic myoclonus of the pelvis and lower limbs which lasted one week, was associated with absent knee and ankle jerks and electrophysiological evidence of a spinal origin for the myoclonus. There was no history of a preceding illness but a CSF pleocytosis and raised protein level suggested a recent (probable viral) infection. These patients did have evidence of CNS inflammation (encephalitis ${ }^{18}$ and myelitis ${ }^{19}$ ) and so were excluded as examples of isolated post-infectious myoclonus according to our criteria.

Why some patients should develop myoclonus without clinical or investigative evidence of structural damage of the CNS following nonspecific or uncomplicated infectious illnesses is unclear. The pathophysiological origin of the myoclonus in our two cases is uncertain. Case 1 , with generalised myoclonus, on one occasion was found to have runs of polyspike/spike potentials at 5-6 Hz on EEG corresponding to her jerks pointing towards a probable cortical origin of the myoclonus. In case 2 , backaveraging of the EEG did not reveal any cortical correlates nor did she have enlarged somatosensory evoked potentials, suggesting that the myoclonus was probably not of cortical origin. No EEG correlates corresponding to the myoclonic jerks were reported in Silfverskiold's cases with rhythmic upper and lower limb myoclonus. ${ }^{17}$ As might be expected therefore it appears that post-infectious myoclonus is a heterogenous entity and that different sites of the CNS can be affected. The underlying pathology is also uncertain.
We thank Dr R F Gledhill for referring case 2.

1 Von Economo C. Encephalitis letharigica: its sequelae and treatment. London: Oxford University Press, 1931

2 Farrel DF, Swanson PD. Infectious diseases associated with myoclonus. In: Charlton MH, ed. Myoclonic seizures. Amsterdam: Excerpta Medica, 1975:77-110.

3 Marsden CD, Hallett $M$, Fahn $S$. The nosology and pathophysiology of myoclonus. In: Marsden CD, Fahn S, eds. Movement disorders. London: Butterworth 1982:196-248.

4 Parain D, Boullocke J. Multifocal epileptic crises following mumps. Neurophysiol-Clin 1988;18:87-91.

5 Swanson PD, Luttrel CN, Magladery JW. Myoclonus-A report of 67 cases and a review of the literature. Medicine 1962;41:339-56.

6 Marinesco MG. Report on a case of myoclonic encephalomyelitis of malarial origin. Brain 1921;44:223-33.

7 Steiner I, Polacheck I, Melamed E. Dementia and myoclonus in a case of cryptococcal encephalitis. Arch Neurol 1984;41:216-7.

8 Dhaliwal GS, McGreal DA. Spinal myoclonus in association with Herpes Zoster infection: Two case reports. Can f Neurol Sci 1974;1:239-41.

9 Hoehn MH, Cherington M. Spinal Myoclonus. Neurology 1977;27:942-6.

10 Kinsbourne $M$. Myoclonic encephalopathy of infants. $f$ Neurol Neurosurg Psychiatry 1962;25:271-6.

11 Kuban KC, Ephros MA, Freeman RL, et al. Syndrome of opsoclonus-myoclonus caused by Coxsackie B3 infection. opsoclonus-myoclonus caused
Ann Neurol 1985;13:623-4.

12 Fahn S, Marsden CD, Van Woert MH. 'Definition and classification of myoclonus. In: Fahn $\mathrm{S}$, et al. eds. classification of myoclonus. In: Fahn S, et al. eds.
Advances in neurology, Vol 43, Myoclonus. New York: Advances in neurology,
Raven Press 1986:1-5.

13 Weiner WJ, Lang AE. Myoclonus and related disorders. In: Weiner WJ, Lang AE, eds. Movement disorders, a comprehensive survey. New York: Futura Publishing 1989:457-530.

14 Aigner RB, Mulder DW. Myoclonus, clinical significance and an approach to classification. Arch Neurol $1960 ; 2: 600-15$

15 Campbell AMG, Garland H. Subacute myoclonic spinal neuronitis. $f$ Neurol Neurosurg Psychiatry 1956; 19:268-74.

16 Bradshaw JPP. Cited by Liversedge LA; Involuntary movements: In: Vinken PJ, Bruyn GW, eds. Handbook of clinical neurology, Vol 1. Amsterdam: North Holland Publishing, neurology, Vol
1969:277-92.

17 Silverskiold BP. Rhythmic myoclonus in three girls. Acta Neurol Scand 1969;38:45-9.

18 Lance JW. Myoclonic jerks and falls: aetiology, classification and treatment. Med $\mathcal{F}$ Aust 1968;4:113-20.

19 Hopkins AP, Michael WF. Spinal myoclonus. F Neurol Neurosurg Psychiatry 1974;37:1112-15.

\section{Early notions of hydrocephalus}

The truth of claims that Hippocrates recognised hydrocephalus and drained the ventricles through the fontanelle is uncertain. Two patients are described in the second edition of Vesalius' De Fabrica $(1555)^{1}$ : in a two year old girl he had obtained "9lbs of water from the ventricles. I marvelled at nothing more than the amount of water had for so long collected in the ventricles of the brain without greater symptoms."

In 1761 Contugno described the cerebrospinal fluid (CSF). ' The remarkable Stockholm mystic, Emmanuel Swedenborg (1688-1772), left manuscripts unpublished until 1882 and 1887 showing that he recognised not only the four ventricles, but also the secretory role of the choroid plexuses and the circulation of CSF through the 4 th ventricle in the medulla, "through a cleft in its ceiling, between the pia and dura mater, and thence to the spinal cord".
The eighteenth century anatomists Morgagni, and the physician Robert Whytt demonstrated the relevant CSF pathways and made some sense of the pathology of hydrocephalus. $^{3}$

In the nineteenth century Magendie (1828), Luschka (1855) and above all, Key and Retzius described the CSF flow and formation. In his "Essay on hydrocephalus acutus" (1808), John Cheyne recorded 23 cases; all but six succumbed and the aetiology in most was probably tuberculous meningitis.'

JMS PEARCE

1 Spillane JD. The doctrine of the nerves. Oxford: OUP 1981:41, 120, 138, 170-6.

2 Davidoff LM. Treatment of hydrocephalus. Historical review and description of a new method. Arch Surg 1929;18:1737-62.

3 Whytt R. Observations on the dropsy in the brain. Edinburgh; J Balfour, 1768. 